\title{
高速双ロールキャスターで作製したアルミニウム合金板に ロール面が及ぼす影響*
}

\author{
山敷 拓也 ${ }^{* 1}$, 羽賀 俊雄 ${ }^{* 2}$, 熊井 真次 ${ }^{* 3}$, 渡利 久規 ${ }^{* 4}$
}

\section{Effect of Roll Surface on Aluminum Alloy Strip Fabricated by a High-Speed Twin Roll Caster}

\author{
Takuya YAMASHIKI ${ }^{* 1}$, Toshio HAGA, Shinji KUMAI and Hisaki WATARI \\ ${ }^{* 1}$ Graduate school of Osaka Institute of Technology, 5-16-1 Omiya Asahi-ku Osaka-city, 535-8585 Japan
}

\begin{abstract}
A vertical type high speed twin roll caster is able to cast an aluminum alloy strip directly from a molten metal that is poured between the rotating rolls. However defects such as small cracks and unsound thickness distribution of the cast strip occur at faster roll speed. They are related to the contact condition of the roll surface and the melt. In the present study, we used the grooved roll to eliminate the defects, and to save the cost at the same time. We experimented using several grooved rolls with different patterns. When the groove width was $0.45 \mathrm{~mm}$; depth $0.2 \mathrm{~mm}$; pitch $0.1 \mathrm{~mm}$ and $1.0 \mathrm{~mm}$, stable casting was possible. The shape of bulge was formed on the cast strip surface by the grooved roll. As a result of the color check, the grooved roll could eliminate the small cracks. The surface condition of the strip was more sound using the grooved roll with the pitch of $0.1 \mathrm{~mm}$ than that of $1.0 \mathrm{~mm}$. Stopping the rotated roll during the casting, we observed the contact condition between the melt and the roll, and confirmed how the bulge was formed. To cold-roll for strip with bulges was possible and the bulges was erased. To cast for the sound strip was possible by the vertical type high speed twin roll caster with grooved rolls.
\end{abstract}

Key Words : Grooved Roll, Aluminum Alloy, Twin Roll Caster, Casting

\section{1. 緒言}

双ロールキャスターは二つの回転するロール間に溶融金属を直接注湯することで，一工程で薄板の作製が可能 である. 先行研究により，アルミニウム合金薄板を従来の鋳造速度に比べ 30 倍から 60 倍の速度で作製を可能に した縦型高速双ロールキャスターが開発された (1)-(3). しかし, 縦型高速双ロールキャスターで作製された薄板は, 合金によっては薄板の表面に割れが生じる場合がある.それは鋳造中のロール面と溶湯の接触状態に関係がある. 表面割れは下工程である冷間圧延などに影響を与えるため改善が必要である.これまでの研究により，ロール面 に凹凸を加えることで薄板の表面割れが抑制される報告がある(4)-(5). その中でも，欠陥の起因になると推測され る鋳造中の接触状態の改善及び, ロールへの加工コストや形状の再現性の点から溝が優れていると考えた.

本研究では, 溝加工を施したロールを装備した縦型高速双ロールキャスターで表面割れがみられやすい 6022 合金を鋳造し，薄板作製の可否及び，溝の条件が薄板の状態に及ぼす影響を調査した.

\section{2. 実験装置及び，鋳造条件が薄板の表面割れに及ぼす影響}

図 1 に縦型高速双ロールキャスター(Vertical type High Speed Twin Roll Caster:VHSTRC)の概略図を示す. 装置は, 樋，ノズル，ロール及び，荷重ばねから構成されている，ロール材質は銅，直径 $300 \mathrm{~mm}$ ，幅 $50 \mathrm{~mm}$ で，離型剤は 使用しない，一方のロールの位置は固定されている，他方のロールは，板厚に追従しロールギャップが変動する

\footnotetext{
${ }^{*}$ 原稿受付 2012 年 12 月 5 日

*1 学生員, 大阪工業大学大学院 工学研究科（干535-8585 大阪府大阪市旭区大宮 5-16-1）

${ }^{*} 2$ 正員, 大阪工業大学

*3 東京工業大学

*4 群馬大学

E-mail:m1m11436@st.oit.ac.jp
} 
機構となっている．回転する二つのロール上で形成された凝固層が，ロール回転方向途中で合流しながら板が形 成される，ノズルを用いることで溶湯体積が小さくなり，溶湯へッド圧を得ることが容易となる．溶湯へッド圧 を高くすることで，ロール面に対する溶湯の接触状態が向上することに加え，ノズル先端におけるメニスカスの 振動を抑制し, 薄板の表面品質の低下の原因となるリップルマークと呼ばれる縞模様の発生を軽減できる ${ }^{(1)}$.

VHSTRC におけるリップルマークの形成過程を図 2 の模式図で示す. 注湯時, ノズル先端に形成されるメニスカ スから凝固層が形成される(図 2(a)). 溶湯ヘッド圧が低くなるほど, 図 2(b), (c)のようにノズル先端のメニスカス が不安定となる．その結果，溶湯とロールの接触状態が非定常となり，溶湯とロール間に生じるギャップによっ て熱伝達の低下した箇所がリップルマークとして薄板の表面に発生する(図 2(c)).

図 3(a)にロール荷重 $0.1 \mathrm{kN} / \mathrm{mm}$ ，(b)にロール荷重 $0.4 \mathrm{kN} / \mathrm{mm}$ で作製した 6022 合金薄板の表面を示す．どちらも， 溶湯との接触面が平坦なロールで鋳造している０.1 kN/mm で鋳造した薄板の表面には白濁箇所がみられる．白 濁箇所は，金属光沢のある箇所よりも板厚が薄く，割れがみられやすい傾向がある．鋳造中の溶湯とロール幅方 向の接触状態の概略を図 4 に示寸，溶湯へッド圧により溶湯とロールの接触状態は向上寸るが，ロール幅方向で は部分的に接触が不完全な箇所があると考えられる，そのため，凝固が終了するまでに凝固状態に差が生じ，割 れが起こると考えられる. 一方, ロール荷重 $0.4 \mathrm{kN} / \mathrm{mm}$ では圧延の効果によって薄板の表面状態は改善される. しかし高ロール荷重ではロール寿命が短くなるため, 鋳造中の溶湯とロールの接触状態を改善し，低ロール荷重 において表面状態の良い薄板の作製が課題である.

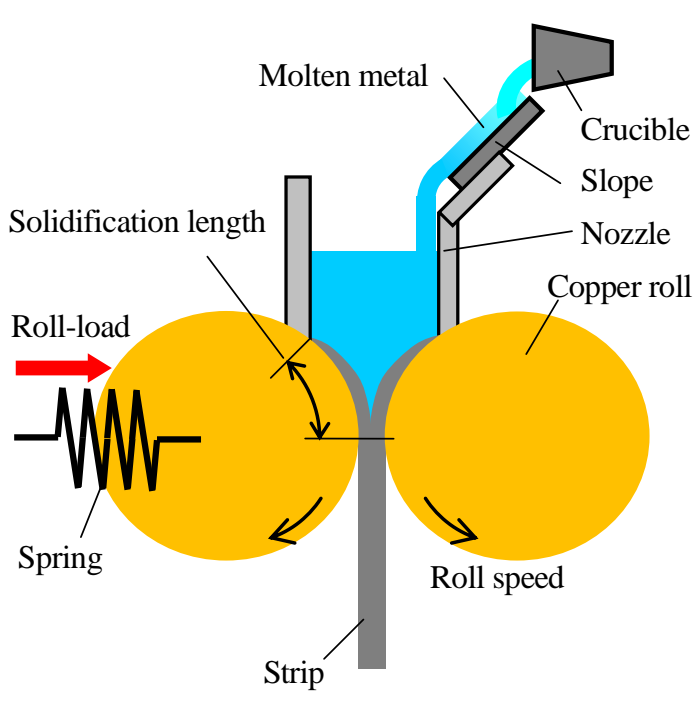

Fig.1 Vertical type High Speed Twin Roll Caster (a)

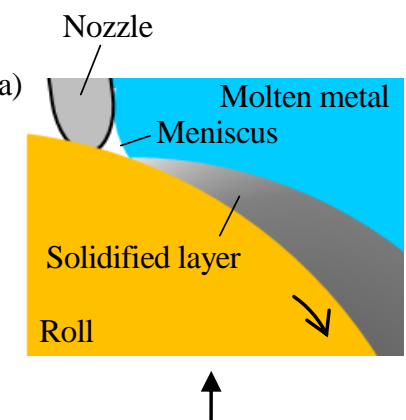

(d)

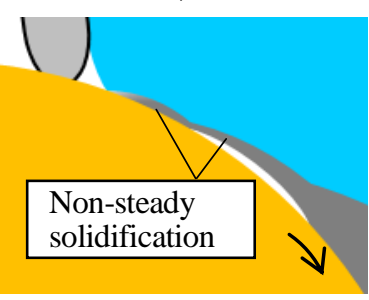

(b)
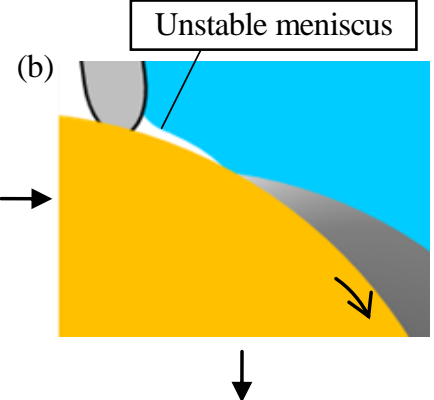

(c)

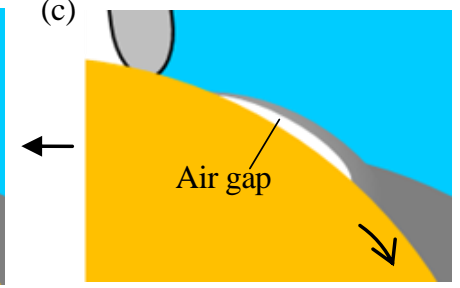

Fig.2 Schematic of the ripple mark formation mechanism
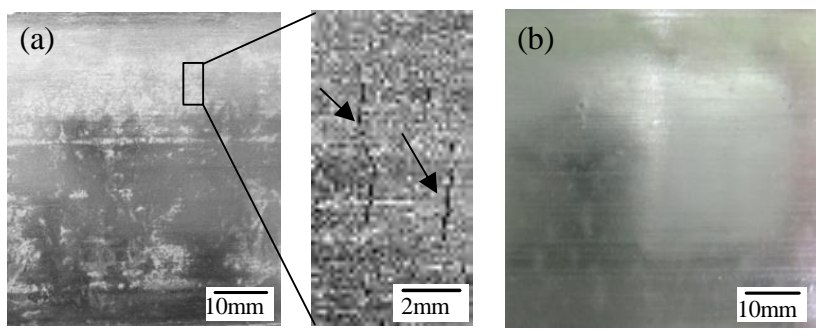

Fig.3 Surface of as-cast strips. (a)As-cast strip cast by $0.1 \mathrm{kN} / \mathrm{mm}$ in roll-load, (b)As-cast strip cast by $0.4 \mathrm{kN} / \mathrm{mm}$ in roll-load

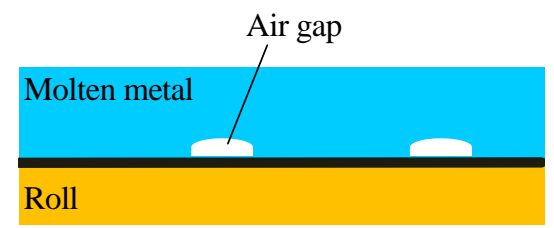

Fig.4 Schematic of contact condition of the melt to the roll width direction

\section{3. 溝ロールと実験条件}

図 5 に鋳造中の溶湯とロールの接触状態を改善寸るために考案した, ロール周方向に溝加工を施したロール(溝 


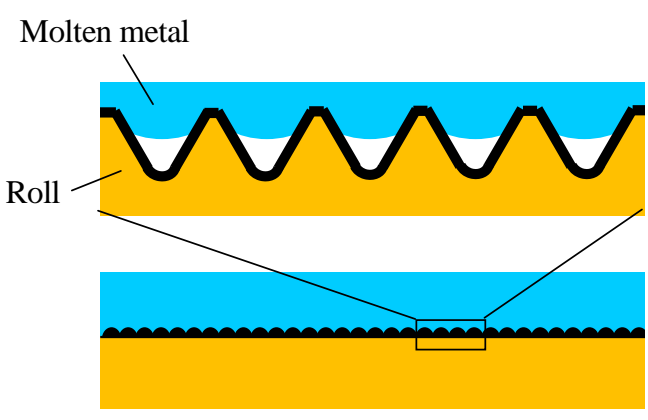

Fig.5 Schematic of ideal contact condition of the melt to the grooved roll (a

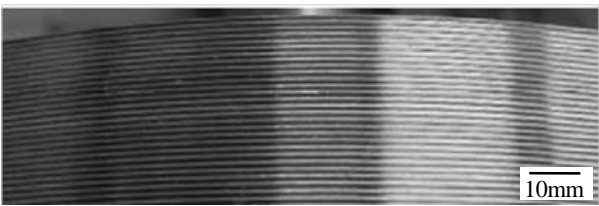

(b)

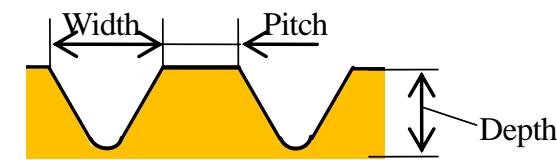

Fig.6 Grooved roll the present study. (a)Surface of the grooved roll, (b) Shape of grooves

ロール）の表面形状の概略図及び，ノズル直下での理想とする溶湯とロールの接触状態の概略図を示す，ノズル 直下で溶湯はロール面の凸部に接触する．そのため，メニスカスが振動しても溝と溶湯の間にできるギャップに よって，溶湯はロール幅方向に均一に接触し，接触状態が定常になると推測した．形成される凝固層の表面は凹 凸になると考えられるが，巨視的にみることにより，ロール幅方向では平坦な凝固層となるため薄板の表面状態 が改善されると推測した．しかし，溝の条件によっては鋳造が困難な場合があると考えられる．溝の幅が広い場 合には，溶湯へッド圧により溶湯が溝の中に入ってしまい，理想とする効果がない可能性がある。一方，溝の幅 が狭い場合には凝固層が溝に詰まり，板がロールに固着する恐れがある.

本研究では, 6 条件の溝ロールを作製した. 図 6 に作製した溝ロールの表面及び, 形状を示寸. 溝の幅は, $0.29 \mathrm{~mm}$, $0.45 \mathrm{~mm} ， 0.57 \mathrm{~mm}$ ，溝同士の間隔を $0.1 \mathrm{~mm}, 1.0 \mathrm{~mm}$ とした．圧延工程に影響のないよう，溝の深さは $0.2 \mathrm{~mm}$ と一 定とした. 供試材は 6022 合金である.ベースとなる鋳造条件は, 注湯量 $1.5 \mathrm{~kg}$, 注湯温度 $675^{\circ} \mathrm{C}\left(\right.$ 液相線 $+20^{\circ} \mathrm{C}$ ), 口ー ル周速 $60 \mathrm{~m} / \mathrm{min}$, 凝固距離 $100 \mathrm{~mm}$ ，ロール荷重 $0.06 \mathrm{kN} / \mathrm{mm}$ とした.

\section{4. 実験結果}

各条件における鋳造中のロールと凝固層または, 溶湯との接触状態について表 1 , 図 7 に示す. 条件によって, 薄板の作製が困難であった．溝の幅 $0.29 \mathrm{~mm}$ では，凝固層が安定して溝から離れられるほどの幅でないために凝 固層が溝に拘束されてしまう場合がある. 間隔 $0.1 \mathrm{~mm}$ は, $1.0 \mathrm{~mm}$ に比べて溝の数が多く, 拘束される箇所も多く なるためロールへの固着や目詰まりが起きたと考えられる(図 7(a)). 0.57mm では鋳造中にチャタリングと呼ばれ るロールの振動が生じ，断続した薄板となって鋳造が困難であった．薄板の表面を観察した結果，メニスカスが 安定する程度の溶湯ヘッド圧を保持していたにも関わらずリップルマークが顕著であった. 溝の幅が $0.57 \mathrm{~mm}$ で は，図 7(c)のように溶湯はロール面との接触開始直後から溝の中を満たし，ロール幅方向における接触状態は不 均一であったと考えられる，さらに，溝により溶湯はロール面からの剥離が容易な状態となり，メニスカスの振 動を圥長する．鋳造方向で不均一な板厚分布となった凝固層がロールキス部を通過するのに伴いロールギャップ が変動するため，チャタリングが生じ，断続した薄板になったと考えられる．溝の幅 $0.45 \mathrm{~mm}$ は，鋳造中に溶湯 が溝の中を満たすことなく， ロール面上の凝固層が離れ易い条件であったと考えられる.

Table1 Result of each experimental

\begin{tabular}{c|c|c|c|c}
\hline \hline No. & Width $[\mathrm{mm}]$ & Pitch $[\mathrm{mm}]$ & Depth $[\mathrm{mm}]$ & Condition during the casting \\
\hline 1 & 0.29 & 0.1 & 0.2 & $\mathrm{a}$ \\
\hline 2 & 0.29 & 1.0 & 0.2 & $\mathrm{~b}$ \\
\hline 3 & 0.45 & 0.1 & 0.2 & $\mathrm{~b}$ \\
\hline 4 & 0.45 & 1.0 & 0.2 & $\mathrm{~b}$ \\
\hline 5 & 0.57 & 0.1 & 0.2 & $\mathrm{c}$ \\
\hline 6 & 0.57 & 1.0 & 0.2 & $\mathrm{c}$ \\
\hline
\end{tabular}



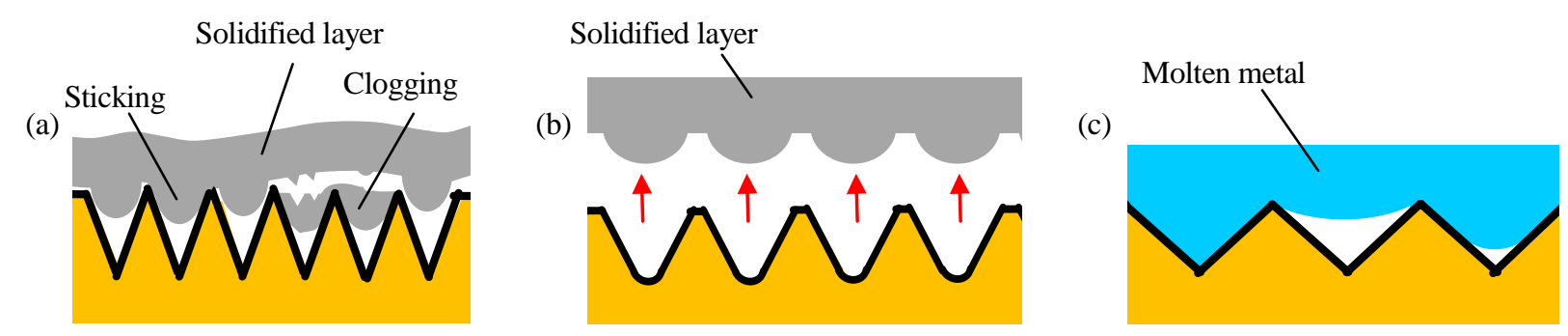

Fig.7 Filling condition in the grooves. (a)Groove width was too narrow, (b)Proper groove width,

(c)Groove width was too thick.

連続して作製が可能であった薄板の表面とカラーチェックの結果を図 8 に示す. 溝ロールで作製した薄板の表 面には凸が形成されており, 金属光沢が板全体にみられた. 板厚は, いずれも凸の高さも含めて $2.8 \mathrm{~mm}$ 程度であっ た. カラーチェックより, 溝ロールで作製した薄板の表面の割れは減少し, 表面状態が改善されていることを確 認した. 表面状態は, 溝の幅 $1.0 \mathrm{~mm}$ と比較し， $0.1 \mathrm{~mm}$ で割れは少なく良い結果を示した. 薄板の断面組織を観察 した結果, 凸部及び, 表面近傍で等軸晶を形成していた.凸部の高さは約 $50 \mu \mathrm{m}$ から $60 \mu \mathrm{m}$ であり, 溝の深さ $0.2 \mathrm{~mm}$ と比較して低かった．また，溝の条件に関係なく凸部の高さに差異はなかった．定常な鋳造が可能であった溶湯 と溝ロールの接触状態を調査するため, 鋳造中のロールの回転を止め, ノズル内で溶湯を凝固させた. 凝固させ た金属を取り出し，ロールとの接触面の断面観察を行った(図 9). ノズル先端である溶湯とロールの接触開始点か らロール荷重を受けていないと推測される位置までは, 凝固層は平坦であった. 凸は, ロール荷重が徐々に加わ るに伴い次第に形成され，ロールキス部付近で最も高かった．接触状態の調查から，溶湯はロール幅方向で溝同 土間の凸部に均一に接触して凝固寸るため平坦な凝固層であったと考えられる. 凝固層の表面は高温で変形能が 高かったため, 凸はロール荷重によって溝に押し込まれて形成される.したがって, 薄板の表面状態は溝によっ て溶湯とロール面の接触状態が均一となったため, 改善されたと考えられる. 線接触ではなく点接触となること で接触状態はより均一となり，溝の間隔 $0.1 \mathrm{~mm}$ で最も良好な表面状態を得られたと考えられる. また，溝によっ て溶湯とロールの接触面が減少し, 凝固時の温度勾配が小さくなったため, 組織は等軸晶であったと考えられる.

作製した薄板を焼鈍しなしで板厚 $1 \mathrm{~mm}$ まで冷間圧延した。いずれの薄板も泠間圧延は可能であり，板表面に 形成された凸による影響はなかった。
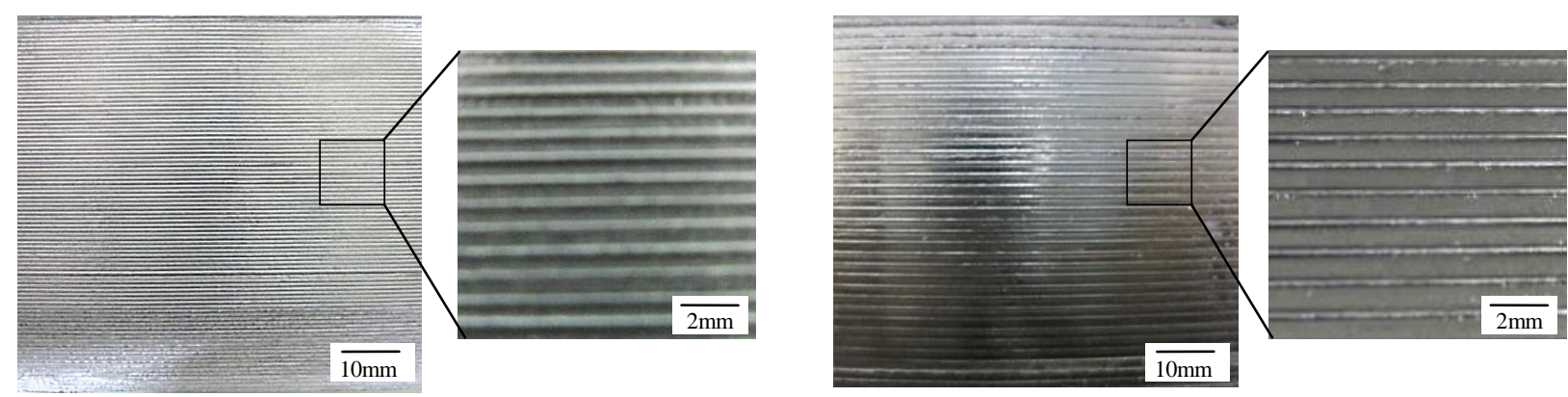

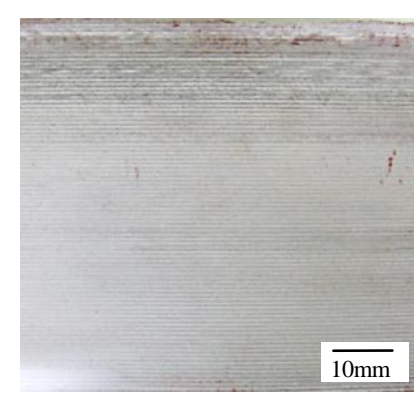

(a) $0.1 \mathrm{~mm}$ in groove pitch

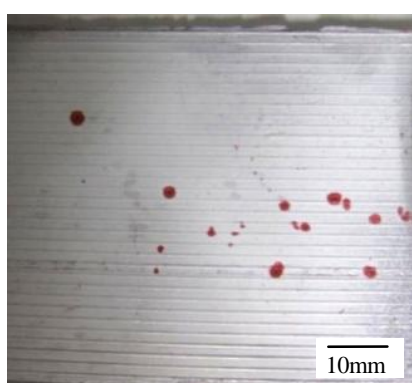

(b) $1.0 \mathrm{~mm}$ in groove pitch

Fig.8 Surface of cast strips. Upper: As-cast strip, Lower: Result of color check 


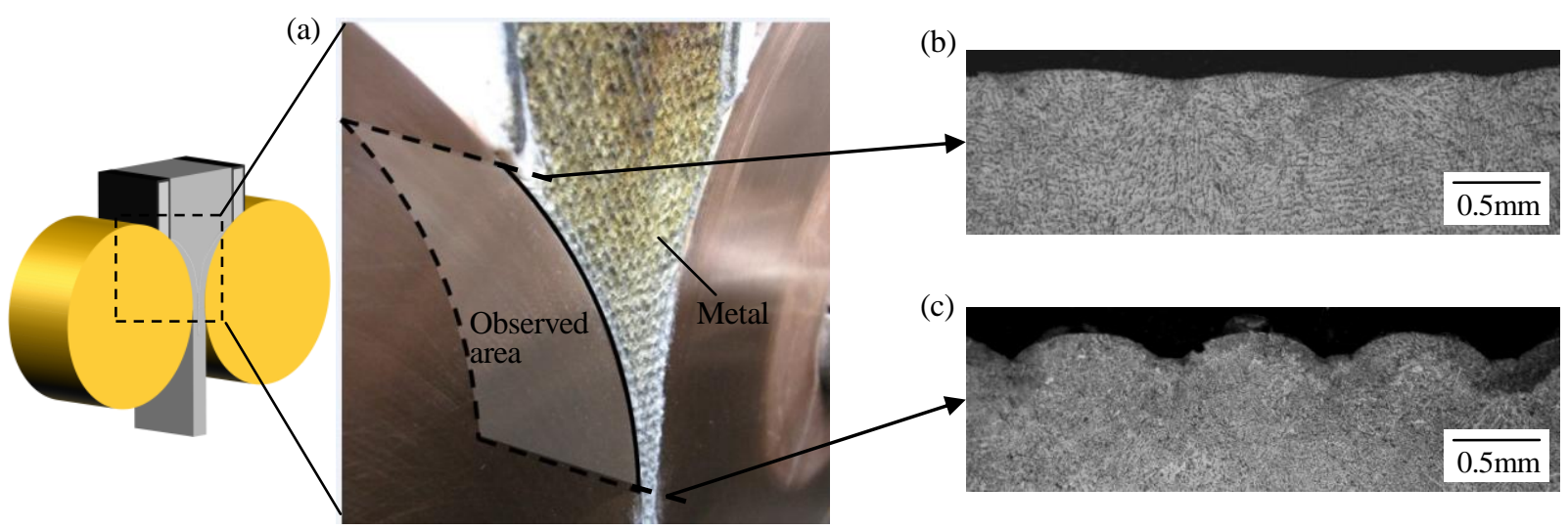

Fig.9 Verification of contact condition of the melt to the grooved roll. (a)Picture of solidified metal and observed area, (b)Cross section of the solidified layer at the starting point of contact to the melt and the grooved roll at the nozzle tip, (c) Cross section of the solidified layer at the roll bite

\section{5. 結言}

本研究では，溝ロールを装備した高速双ロールキャスターで，低ロール荷重で鋳造した場合に板表面に割れの みられやすい 6022 合金薄板の作製を行い，ロール面が板表面に及ぼす影響を調査した.

溝の条件によって連続した薄板の作製が可能であり，表面割れは減少した，溝の幅 $0.45 \mathrm{~mm}$, 溝の間隔 $0.1 \mathrm{~mm}$ の溝ロールで作製した薄板は, 最も表面状態が改善された. 薄板の表面にはロール面の溝の影響で凸が形成され るが, 冷間圧延に影響はなかった. 鋳造中の溶湯とロールの接触状態が改善されたため, 高速双ロールキャスター で作製された薄板の表面状態は改善されたと考えられる.

\section{文献}

(1) T. Haga, H. Sakaguchi, H. Watari, S. Kumai, "High speed twin roll caster for aluminum alloy thin strip", Journal of Achievements in Materials and Manufacturing Engineering, Vol.24(2007), pp. 365-371.

(2) T. Haga, M. Ikawa, H. Watari, S. Kumai, "High speed twin roll casting of Al-3Si-0.6Mg strip", Journal of Achievements in Materials and Manufacturing Engineering, Vol.17(2006), pp. 337-340.

(3) T. Haga, M. Mtsuo, D. Kunigo, Y. Hatanaka, R. Nakamuta, H. Watari, S. Kumai, "Roll casting of 5182 aluminum alloy", Journal of Achievements in Materials and Manufacturing Engineering, Vol.34(2009), pp. 172-179.

（4）SOLLAC，2 本ロール連続鋳造法による炭素鋼ストリップの製造方法，日本国特許第 301295 号（2000）.

（5）新日本製鐵株式会社，双ドラム式連続鋳造装置用冷却ドラムおよび連続鋳造法，日本国特許第 353559 号（2001）. 